\title{
Effects of gamma radiation in okra's conservation
}

\begin{abstract}
Okra is a very important vegetable in simple world cuisine. The aim of this work was to evaluate the effects of gamma radiation of Cobalt-60 in the conservation of okra (Abelmoschus esculentus). After 1 day of okras's harvest, they were selected based in the size, presence of mechanical and phytophatologycal damages, and put in polystyrene trays and covered with thin polyethylene film. Then they were irradiated with doses of: 0 (control); 75; 100; $125 ; 150$ and $200 \mathrm{~Gy}$, at a dose rate of $0.259 \mathrm{kGy} / \mathrm{h}$. The experiment was carried out in chamber regulated at $10 \mathrm{o} \mathrm{C}$ of temperature and $80 \%$ of relative humidity. All analyses physical and chemical of the samples were carried out after 7 and 15 days of the storage. The results did not show any significative difference between the control and irradiated samples, except the viscosity that decreased with the increase of the dose of radiation. The dose of $75 \mathrm{~Gy}$ can be indicated to the conservation of okras because it was the one that showed best result in the coloration of okras.
\end{abstract}

Keywords: Abelmoschus esculentus, food physico-chemical analysis, food radiation, Ionizing radiation, okra shelflife
Volume 5 Issue 3 - 202I

\author{
Paula Bergamin Arthur,' Rodrigo Sebastião \\ Rossi Leandro,' Larissa Nalesso Costa \\ Harder,' Marcia Nalesso Costa Harder, ${ }^{1,2}$ \\ Valter Arthur ${ }^{\prime, 3}$ \\ 'Nuclear and Energy Research Institute, São Paulo, Brazil \\ ${ }^{2}$ Technology College of Piracicaba, Piracicaba, São Paulo, Brazil \\ ${ }^{3}$ Radiobiology and Environment, Center of Nuclear Energy in \\ Agriculture, Brazil
}

Correspondence: Valter Arthur, Center of Nuclear Energy in Agriculture, Av. Centenário, 303, Piracicaba, São Paulo, Brazil, 5519 34294665, Email arthur@cena.usp.br

Received: May 30, 2021 | Published: June 16, 2021

\section{Introduction}

Popularly known as okra plant, the species Abelmoschus esculentus L. Moench is the plant that produces okra, a very important vegetable in Brazilian cuisine. There are approximately 30 different varieties of okra (A. esculentus), being all of them results from crossbreeding and these plants grow (up to $2.5 \mathrm{~m}$ in height) preferentially in warm; fertile; humid and clay soil environments. The lobed and furry leaves are between 20 and $30 \mathrm{~cm}$ in length. The magnificent flowers are yellow color with a red or pink color heart. The fruit is a capsule whose color can be green, violet, red or white depending on the cultivars.

Are supposed that the okra was originated in tropical Africa, although there are other hypotheses, such as Egypt, where the Nile River could have provided the plant's development and it was brought to Brazil through the slave trade. ${ }^{2}$ Nowadays it is cultivated mainly in Asia, the Middle East and the South of the USA..$^{3-5}$

Okra is a very common vegetable on people dishes around the world and it is generally consumed cooked and its consumption brings a lot of benefits, once it is a source of mineral salts, carbohydrates, proteins and vitamins, in addition to contributing to the proper functioning of the digestive system by presenting long-chain polysaccharides.$^{1}$ It has several medicinal properties, among which stand out the anti-diabetic and antioxidant action of powdered husks and seeds, based on studies with rats, ${ }^{6}$ and action in cholesterol reducing. ${ }^{1}$

About its benefits, okra is a vegetable that also has a great source of hydrophilic polysaccharides, called mucilage, which form a viscous solution with water and is known commercially as hydrocolloid because of this property. In the food and pharmaceutical industrial sectors, mucilages are very important, since they can be used as thickeners, stabilizing emulsions, suspending agents, binders, etc. ${ }^{7}$

The contained vitamin $\mathrm{C}$ is not used by the body because it is lost in the cooking. However, this vegetable is rich in vitamin A, good for the skin, mucous membranes in general and the eyesight. Due to it contains vitamins of the B Complex, it helps in the growth process.
And its mineral salts, such as Calcium, Phosphorus, Iron and Copper help in the formation of bones, teeth, blood, in addition to providing energy for the whole body. It has a viscous gum, little appreciated. With low calorie content, it is easy to digest, being recommended for people who have digestive problems. ${ }^{8}$

It is a vegetable with low calories and rich in starch with a high phosphate content. It is also a rich source of antioxidant vitamins A and $\mathrm{C}$ and potassium, which is an electrolyte that maintains the balance of fluids in the body and helps to transmit nerve impulses, in addition it is necessary for muscle exercise and metabolism. Its viscosity does not please some people, but it is an excellent way to thicken soups and stews. After harvesting, the okra must be consumed quickly because it gets withered, fibrous and then darkens. It cannot tolerate very low temperatures for a long time, as they get dark and deteriorate. Therefore, it should be placed in the bottom of the refrigerator, inside plastic bags. In this condition, it can be conserved up to a week. ${ }^{8}$

For this author, okra is a very perishable vegetable, deteriorating quickly. Post-harvest conservation does not aim to improve the qualities of fruits and vegetables, but rather to preserve them for a longer period, consequently reducing the natural aging process, so the product reaches the consumer without changes in its nutritional value in relation to the physical-chemical and sensory characteristics, consequently conserving plant products for a longer time avoiding losses and increasing producers' profits. ${ }^{9}$

Food conservation through physical methods has been known and used for a long time. The use of cold was one of the first methods utilized to extend the shelf life of food, especially meat. With the evolution of technological food preservation processes, it was observed more than a half century ago that gamma radiation from Cobalt-60 or Cesium-137, or even accelerated electrons, is capable to destroying pathogenic microorganisms, which can cause serious diseases or consumer death. ${ }^{10}$ Ionizing radiation has the advantage of reducing or even paralyzing fruit ripening processes. As a result, an extension of the fruit and vegetable shelf life is obtained with considerable economic advantages. ${ }^{11}$ 
Ahmed $^{12}$ drew attention to the food irradiation needing to give consumers not only a better-quality option, due to the elimination of microorganisms by radiation, but also offer a greater variety of products, which after being irradiated can be consumed even in nontraditional times, including fruits, vegetables, condiments and spices. The food irradiation process is a method that is nothing more than the controlled exposure of the food to a source that emits ionizing radiation. ${ }^{13,14}$

Recently, the irradiation process is used as a very efficient alternative method when it is applied in doses up to $10 \mathrm{kGy}$ mainly in dry, dehydrated and low-fat foods..$^{13}$ Many studies used the irradiation process to reduce the microbial load and phytosanitary treatment aiming a better-quality product with a longer shelf life. ${ }^{15-18}$

In addition, the process triggers some changes in the physicalchemical characteristics of the products that can be used increasing their technological application, as in the case of the irradiated flour used in bread making, improving its performance in the preparation of breads. ${ }^{19,20}$ To add value in the area of food irradiation, many studies show that the use of different doses of radiation can improve the properties' quality of some agricultural products. ${ }^{18}$

The irradiation applied to fruits and vegetables in the post-harvest has as main objective the reduction of the damages caused by diseases and pests, acting as an alternative method to the chemical products. It has also been used as a conservation process, quarantine treatment, prolonging storage, delaying ripening and inhibiting the sprouting of some products.?

The aim of the study was to evaluate the effects of gamma radiation on the physical and chemical characteristics of okra with a view to increasing its useful life.

\section{Material and methods}

Okra were purchased from ESALQ's Horticulture Department and taken to the Food Irradiation and Radio entomology Laboratory of the Nuclear Energy Center in Agriculture (CENA/USP), where they were selected about the size and absence of mechanical and phyto pathological damage. Then they were placed in styrofoam trays $(21 \mathrm{x}$ $21 \mathrm{~cm}$ ), which were covered with plastic film (PVC).

After making the trays, they were irradiated one day after harvesting in a Cobalt-60 radiator, type Gammabeam 650, with doses of 0 (control); 75; 100; 125; 150 and $200 \mathrm{~Gy}$, under a rate of dose of $0.259 \mathrm{kGy} \cdot$ hour $^{-1}$, and each treatment consisted of 4 repetitions and stored at $10^{\circ} \mathrm{C}$ and $80 \% \mathrm{RH}$.

Dosimetry was performed using $5 \mathrm{~mm}$ diameter alanine dosimeters (Bruker Instruments, Rheinstetten, Germany), and the free radical signal was measured with Bruker EMS 104 EPR Analyzer. The actual dose was within 0.02 of the target doses. Samples was turned 360 continuously during the irradiation process to achieve uniform target doses and the non irradiated control was placed outside the irradiation chamber to have the same environmental temperature effect with the irradiating sample.

After 7 and 15 days from the irradiation, it was evaluated the physico-chemical analyses.

\section{Physico-chemical analysis}

\section{Color}

The colorimeter Minolta CR-200 b was used, previously calibrated in White according to pre-determined standards, according to. ${ }^{21}$
Three values of chroma were evaluated: $a^{*}, b^{*}$ and $L$. The value $\mathrm{a}^{*}$ characterizes the color from the red $\left(+\mathrm{a}^{*}\right)$ to the green $\left(-\mathrm{a}^{*}\right)$; the value $b^{*}$ indicates the color from the yellow $\left(+b^{*}\right)$ to the blue $\left(-b^{*}\right)$. The value $\mathrm{L}$ determines the light ranging from white $(\mathrm{L}=100)$ to black $(\mathrm{L}=0)$. The chroma is the ratio between $\mathrm{a}^{*}$ and $\mathrm{b}^{*}$, where the real color can be obtained. Hue-Angle is the angle between $a^{*}$ and $b^{*}$, indicating the color saturation of the analyzed object (Harder, 2005; Harder et al., 2007).

To estimate chroma value, the following formula was adopted (1) and to estimate the Hue-Angle, formula (2).22

$$
\begin{aligned}
\mathrm{C} & =\sqrt{ }(\mathrm{a} 2+\mathrm{b} 2) \\
\mathrm{H}^{\mathrm{o}} & =\operatorname{arcpg} \mathrm{b}^{*} / \mathrm{a}^{*}
\end{aligned}
$$

\section{Soluble solids content}

Estimated by direct reading in bench refractometer RT-30ATC and expressed in ${ }^{\circ}$ Brix, according to AOAC. ${ }^{23}$

\section{pH}

Determined by direct reading and using bench $\mathrm{pH}$ meter MB-10, with methodology according to AOAC..$^{23}$

\section{Viscosity}

Determined by direct reading and using viscosimeter Brookfield, with methodology according to AOAC. ${ }^{23}$

\section{Statistical analysis}

The experimental design was complete randomized with three replications. Results were analyzed (ANOVA) using the F test, and mean comparisons were tested based on Tukey $(p<0,05)$ using SAS. ${ }^{24}$

\section{Results}

From the results obtained, it could be seen that there was no significant difference at the level of $5 \%$ with respect to radiation doses in the storage periods for the color values (Table 1).

Table I Mean values and standard deviation of the okra color samples irradiated with different doses of gamma radiation after 7 and 15 days of storage

\begin{tabular}{lll}
\hline Dose (Gy) & 7 days & I 5 days \\
\hline 0 (Control) & $51.05 \pm 0.10 * a * *$ & $45.55 \pm 0.20 \mathrm{a}$ \\
75 & $52.38 \pm 0.13 \mathrm{a}$ & $51.65 \pm 0.1 \mathrm{Ia}$ \\
100 & $50.33 \pm 0.11 \mathrm{a}$ & $49.23 \pm 0.15 \mathrm{a}$ \\
125 & $51.44 \pm 0.15 \mathrm{a}$ & $49.04 \pm 0.13 \mathrm{a}$ \\
150 & $50.61 \pm 0.17 \mathrm{a}$ & $48.51 \pm 0.18 \mathrm{a}$ \\
200 & $51.16 \pm 0.16 \mathrm{a}$ & $48.01 \pm 0.14 \mathrm{a}$
\end{tabular}

* Media \pm standard deviation

** Equal letter values in column do not differ statistically by Tukey's test at $5 \%$ significance level

It can be seen by the results presented in Table 2 that there was not significant difference at the level of $5 \%$ in relation to the radiation doses and the control in the storage periods for the $\mathrm{pH}$ values. 
Table 2 Mean values and standard deviation of the $\mathrm{pH}$ samples of okra irradiated with different doses of gamma radiation after 7 and 15 days of storage

\begin{tabular}{lll}
\hline Dose (Gy) & 7 days & I5 days \\
\hline 0 (Control) & $6.01 \pm 0.15^{*} \mathrm{a} * *$ & $5.10 \pm 0.12 \mathrm{a}$ \\
75 & $6.10 \pm 0.10 \mathrm{a}$ & $5.80 \pm 0.14 \mathrm{a}$ \\
100 & $6.15 \pm 0.13 \mathrm{a}$ & $5.40 \pm 0.13 \mathrm{a}$ \\
125 & $6.18 \pm 0.16 \mathrm{a}$ & $5.05 \pm 0.16 \mathrm{a}$ \\
150 & $6.11 \pm 0.14 \mathrm{a}$ & $5.10 \pm 0.11 \mathrm{a}$ \\
200 & $5.75 \pm 0.12 \mathrm{a}$ & $4.55 \pm 0.14 \mathrm{a}$ \\
\hline
\end{tabular}

* Media \pm standard deviation

** Equal letter values in column do not differ statistically by Tukey's test at $5 \%$ significance level

According to the values obtained, it could be observed that there was a significant difference at the level of $5 \%$ in relation to the radiation doses in the storage periods for the values of soluble solids, decreasing significantly with doses above 75 Gy (Table 3 ).

Table 3 Mean values and standard deviation of the soluble solids samples of okra irradiated with different doses of gamma radiation after 7 and 15 days of storage

\begin{tabular}{lll}
\hline Dose (Gy) & $\mathbf{7}$ days & I5 days \\
\hline 0 (Control) & $6.00 \pm 0.09 * \mathrm{a} * *$ & $4.55 \pm 0.12 \mathrm{a}$ \\
75 & $5.85 \pm 0.13 \mathrm{a}$ & $5.65 \pm 0.16 \mathrm{a}$ \\
100 & $5.27 \pm 0.11 \mathrm{~b}$ & $5.00 \pm 0.17 \mathrm{~b}$ \\
125 & $5.55 \pm 0.15 \mathrm{~b}$ & $5.01 \pm 0.13 \mathrm{~b}$ \\
150 & $5.56 \pm 0.14 \mathrm{~b}$ & $4.42 \pm 0.11 \mathrm{~b}$ \\
200 & $5.42 \pm 0.12 \mathrm{~b}$ & $4.52 \pm 0.14 \mathrm{~b}$ \\
\hline
\end{tabular}

* Media \pm standard deviation

** Equal letter values in column do not differ statistically by Tukey's test at $5 \%$ significance level

From the results presented in Table 4, can be seen that there was a significant difference in the level of $5 \%$ in relation to the doses of gamma radiation and the control treatment in the periods of 7 and 15 days of storage for the viscosity values. We could observe that in the two storage periods with the dose of 75 Gy there was a marked decrease in the viscosity of the okra samples in relation to the control treatment and the other treatments with irradiation, probably the effect of the radiation had affected the hydrocolloids which are polysaccharides existing in the okra gum.

Table 4 Mean values and standard deviation of the viscosity samples of okra irradiated with different doses of gamma radiation after 7 and 15 days of storage

\begin{tabular}{lll}
\hline Dose $(\mathbf{G y})$ & $\mathbf{7}$ days & I 5 days \\
\hline 0 (Control) & $21.25 \pm 0.20 * \mathrm{a} * *$ & $18.1 \mathrm{II} \pm 0.2 \mathrm{I}^{\mathrm{a}}$ \\
75 & $9.25 \pm 0.12 \mathrm{~b}$ & $8.35 \pm 0.15 \mathrm{~b}$ \\
100 & $5.50 \pm 0.21 \mathrm{c}$ & $4.40 \pm 0.17 \mathrm{c}$ \\
125 & $4.00 \pm 0.1 \mathrm{lc}$ & $3.20 \pm 0.13 \mathrm{c}$ \\
\hline
\end{tabular}

\begin{tabular}{lll}
\multicolumn{3}{l}{ Table Continued... } \\
\hline Dose $(\mathbf{G y})$ & $\mathbf{7}$ days & $\mathbf{1 5}$ days \\
\hline 150 & $4.25 \pm 0.14 \mathrm{c}$ & $3.15 \pm 0.17 \mathrm{c}$ \\
200 & $4.75 \pm 0.18 \mathrm{c}$ & $3.85 \pm 0.16 \mathrm{c}$ \\
\hline
\end{tabular}

* Media \pm standard deviation

** Equal letter values in column do not differ statistically by Tukey's test at $5 \%$ significance level

\section{Discussion}

Most works on the application of gamma radiation or ionizing energies in okra, mainly aim at mutagenic changes in okra plants, as is the case of the Nizamani et al. ${ }^{25}$ studies, changing production characteristics, such as quantity and size of fruits, quantity of seeds, among other parameters.

It also relies on the use of gamma radiation to aid in the polymerization process of okra mucilage, as is the case in the work of Raj et al. ${ }^{26}$ where he points out other literature dealing with this subject.

However, there are few works that consider the increase in shelf life of okra destined for foodor even evaluate the characteristics of okra after using radiation to increase shelf life.

The results obtained in Table 1 match with the evaluations carried out by Bhering et al. ${ }^{27}$ who observed a decrease in the values of okra color for a storage of 14 days. What is observed in the work "Color change kinetics of okra undergoing microwave drying" by Dadali et al. ${ }^{28}$ too.

Disagreeing with the results and previous authors, Ofori-Appiah ${ }^{29}$ did not find significant differences for okra color in different doses $(0 ; 5 ; 10$ and $20 \mathrm{kGy})$ and in different storage dates. This author only found a color difference in the way the product was manufactured.

The results obtained by Ofori-Appiah ${ }^{29}$ match with the values presented in this work at Table 2. For the $\mathrm{pH}$ parameter, it obtained values that were from 5.86 to 6.4 even for higher doses (20kGy), not finding significant statistical differences among the values found, even in the 3-month storage period.

For Table 3, even not using radiation as a control method, Jesus et al. ${ }^{30}$ observed a significant drop in the values of soluble solids for minimally processed okra and subjected to browning control methods. The values found by the authors were equivalent to those found in this work.

Such values are corroborated by the results found in the studies by Moreira et al. ${ }^{31}$ in minimally processed okra treated with ascorbic acid $(2 \%)$ and citric acid (2\%) and by Arruda et al. ${ }^{32}$ in sliced melons.

Such values for viscosity at Table 4 are corroborated with the observations found by Ofori-Appiah ${ }^{29}$ who also observed a significant decrease in viscosity with an increase in irradiation doses. ${ }^{33,34}$

\section{Conclusion}

From the results obtained, it could be concluded that doses of gamma radiation up to $200 \mathrm{~Gy}$ did not alter the physical-chemical characteristics of okra, except for the viscosity that decreased with the increase in the radiation dose.

The dose of 75 Gy can be indicated for the conservation of okra, since it was the dose that presented the best results for all parameters evaluated. 


\section{Funding}

None.

\section{Acknowledgments}

None.

\section{Conflicts of interest}

The authors declare that they have no known competing financial interests or personal relationships that could have appeared to influence the work reported in this paper.

\section{References}

1. Santos IF. Determinação e avaliação quimiométrica da composição mineral do Abelmoschus esculentus L. comercializados na cidade de Salvador. Federal University of Bahia. Salvador. 2013;79.

2. Wright CA. Mediterranean vegetables. The Harvard Common Press, Massachusetts. 2001

3. Sengkhamparn N. Chemical, physical and biological features of okra pectin. Wageningen University. Wageningen. 2009;176.

4. Sengkhamparn N, Sagis LM, de Vries R, et al. Physico-chemical properties of pectins from okra (Abelmoschus esculentus (L.) Moench). Food Hydrocoll. 2010;24;35-41.

5. Sengkhamparn N, Verhoef R, Schols HA, et al. Characterisation of cell wall polysaccharides from okra (Abelmoschus esculentus (L.) Moench). Carbohydr Res. 2009;28:1824-1832.

6. Panneerselvam K, Ramachandran S, Sabitha V, et al. Ant idiabetic and anti-hyperlipidemic potential of Abelmoschus esculentus (L.) Moench. in streptozotocin-induced diabetic rats. J Pharm Bioall Sci. 2011;3;397-397.

7. Archana G, Sabina K, Babuskin S, et al. Preparation and characterization of mucilage polysaccharide for biomedical ap- plications. Carb Pol. 2013;98;89-94.

8. Dantas T. Quiabo. In: https://brasilescola.uol.com.br/saude/quiabo.html..

9. Wiendl, FM, Arthur V. Conservação de pimentões (Capsicum annum L.) através da radiação gama do Cobalto-60. Revista de Agricultura. $1996 ; 71 ; 21-32$.

10. Kaferstein FK. Safe food more needed than ever before. Press Released of the World Health Organization. 1993;86.2p.

11. Loaharanu P. Cost/ benefit aspects of food irradiation. Food Technology 1994;104-108.

12. Ahmed M. Up to Date Status of food irradiation, in: conference abstracts of the -8 international meeting on radiation processing. 1992;85-85.

13. Ehlermann DA. Wholesomeness of irradiated food. Rad Phys Chem. 2016;129:24-29.

14. Ihsanullah I, Rashid A. Current activities in food irradiation as a sanitary and phytosanitary treatment in the Asia and the Pacific Region and a comparison with advanced countries. Food Cont. 2007;72:345-359.

15. Hilsenrath FC. Estudo do impacto da irradiação sobre a qualidade do trigo e da farinha de trigo. São Paulo. São Paulo University.. 2005;61.
16. Marathe SA, Machaiah JP, Rao BYK, et al. Extension of shel flife of wholewheat flour by gamma radiation. Int JFood Sci Techn. 2002;37:163-168.

17. Oliveira AC. Avaliação dos efeitos da radiação gama nas características físico-químicas de kiwi Actinidia deliciosa cv. Hayward minimamente processado. Energetic and Nuclear Research Institute. São Paulo. 2011;51.

18. Arthur V, Pedroso BM, Arthur PB, et al. Irradiação de mandioca minimamente processada. Tecn Ciên Agrop. 2016;10:62-67.

19. Singer CS. Propriedade físico-química, reológica, entálpicas e de panificação da farinha obtida de trigo irradiado. São Paulo. São Paulo University. 2006;120.

20. Texeira CAHM. Efeito da radiação ionizante em diferentes tipos de farinhas utilizadas em tecnologia de panificação. São Paulo. Energetic and Nuclear Research Institute. 2011;159.

21. Bible BB, Singha S. Canopy position influences cielab coordinates of peach color. Hort sci. 1997;28:992-993.

22. Estevez M, Cava R. Lipid and protein oxidation, release of iron from heme molecule and colour deterioration during refrigerated storage of liver pate. Meat Sci. 2004;68:551-558.

23. AOAC. Official methods of analysis of AOAC international. AOAC.

24. SAS Institute. SAS/QC software: usage and reference (version .9.2). Cary, $\mathrm{NC}, 2005$.

25. Nizamani MM. Effect of chemical mutagens on growth of Okra (Abelmoschus esculentus L. Moench). Pure Appl Biol. 2020; 9:1110-1117.

26. Raj V, Shim JJ, Lee J. Grafting modification of okra mucilage: Recent findings, applications, and future directions. Carb Pol. 2020;116653.

27. Bhering AS, Vieira JCB, Puiatti MLSO, et al. Avaliação pós-colheita de Quiabo cultivado em sistema de consorcio e solteiro. Hort Bras. 2005;30:3493-3499.

28. Dadali G, Apar DKBÖ. Color change kinetics of okra undergoing microwave drying. Dray Techn. 2007;25:925-936.

29. Ofori-Appiah D. Decontamination of sliced and powdered okra (Abelmoschus esculentus) and some aspects of nutrient quality before and after gamma irradiation. Bibliographic information available from INIS. 2012.

30. Jesus MMS, Carnelossi MAG, Santos SF, et al. Inhibition of enzymatic browning in minimally processed okra. Rev Ciên Agron. 2008;39:524 530 .

31. Moreira GC. Qualidade tecnológica de quiabo minimamente processado e armazenado sob refriger- ação. In: II Simpósio Brasileiro de pós-colheita, 04. Viçosa. UFV. Palestras e Resumos. Viçosa: UFV. 2007;361.

32. Arruda, MC, Jacomino AP, Kluge R, et al. Temperatura de armazenamento e tipo de corte para melão minimamente processado. Rev Bras Frut. 2003;25:74-76.

33. Bashir K, Swer TL, Prakash KS, et al. Physico-chemical and functional properties of gamma irradiated whole wheat flour and starch. Food Sci Techn. 2017;76:131-139.

34. Chitarra MIF, Chitarra AB. Pós-colheita de frutos e hortaliças: fisiologia e manuseio. 2. ed. rev. e ampl. Lavras: UFLA. 2005;783. 